\title{
Mitigation Strategies for Wet Market Food Safety Hazards to Prevent Coronavirus or Other Pathogen Outbreaks
}

\author{
Markus Walkling-Ribeiro ${ }^{1,2 *}$ and Limei Cha ${ }^{3,4}$ \\ ${ }^{1}$ Biotechnology and Food Engineering, Guangdong Technion Israel Institute of Technology (GTIIT), China \\ ${ }^{2}$ Biotechnology and Food Engineering, Technion Israel Institute of Technology (IIT), Israel \\ ${ }^{3}$ Materials Science and Engineering, Guangdong Technion Israel Institute of Technology (GTIIT), China \\ ${ }^{4}$ Materials Science and Engineering, Technion Israel Institute of Technology (IIT), Israel
}

*Corresponding author: Markus Walkling-Ribeiro, Sustainable Food Safety and Process Engineering Lab, Biotechnology and Food Engineering, Guangdong Technion Israel Institute of Technology (GTIIT), China.

Received Date: March 05, 2020

Published Date: March 10, 2020

\section{Abstract}

Due to the most recent outbreak of the severe acute respiratory syndrome coronavirus 2 (SARS CoV2), having spread on a worldwide scale and associated with a wet market in Wuhan, Hubei Province, China, as the initial source of human virus infection, the need for systematic food safety engineering of wet markets is urgent.

Food safety hazards in wet markets are reviewed concisely in this work and different mitigation strategies are discussed, that are likely to have an immediate impact on potential hazards and aim at minimizing the chance of foodborne pathogen occurrences and transmissions at these markets. Moreover, the topic of pathogen detection and traceability is raised as a prerequisite for advocating the perpetuation of wet markets in addition to their cultural and existential significance.

Keywords: Wet markets; Food safety engineering; Mitigation strategies; SARS coronavirus outbreak; Foodborne pathogens; Antibiotic resistance; Wild animals and Peridomestic mammals; Transmission pathways; Hurdle prevention and Consumer protection; Hazard detection and Traceability

Abbreviations: WHO-World Health Organization; SARS-Severe Acute Respiratory Syndrome; GMP-Good Manufacturing Practice; HACCP-Hazard Analysis and Critical Control Point

\section{Introduction}

With an emerging coronavirus disease 2019 (COVID-19) pandemic looming on the horizon and the maximum risk level declared by the WHO [1], not only global containment of the SARS coronavirus 2 is a priority but also its mitigation [2]. At present the latter is typically related to quarantine of those infected and decontaminating associated contact persons and sources. However, some wet markets still operate unmitigated in China [3] as well as in other regions around Asia and in other parts of the world, whereas the wet market in the city of Wuhan, Hubei Province, which was suspected as original source of animal to human transmission has been shut down as well as others in large cities in China for the moment [4]. Following avian influenza (H5N1) outbreaks in Hong Kong in 1997 and 1999 with virus transmission from chickens to humans as well as the first outbreak of SARS coronavirus (CoV) in Guangdong Province, China in 2002, for which the original source of contamination has also not been determined to date but is also thought to originate from an animal reservoir, many wet markets have continued to operate as before, posing significant food safety hazards, while a few wet market locations started with setting up counter-measures, for instance, centralized abattoirs instead of 
on-site animal slaughter and the ban of wild animals sale [5,6]. Although wet markets are an integral part of culture, a traditional source for affordable and locally produced food, a place to meet and socialize, and many people depend on them to secure their livelihood in many countries around the world [7-12], with the death toll rising from the current coronavirus and the challenge to prevent pathogen outbreaks in mind many scientists in China and elsewhere have recently voiced their opinion to abolish (wildlife) wet markets $[13,14]$. However, due to the high transmissibility and rapid propagation of coronavirus [15] and other pathogens $[11,16,17]$ and the likely migration across borders [18], a ban of wet markets would require all countries, where these markets can be found, to take this action in order to become an effective solution, which seems to be unlikely. By contrast, existing food safety hazards of wet markets and different strategies for pathogen mitigation are reviewed and examples for their implementation provided, thereby, effectively addressing the urgent imperative to engineer sufficient food safety solutions for wet markets (Table 1).

Table 1: Overview of mitigation strategies to minimize food safety hazards of wet markets.

\begin{tabular}{|c|c|c|}
\hline Food Safety Hazard & Mitigation Strategy & Implementation Examples \\
\hline $\begin{array}{l}\text { Insufficient knowledge of or commitment } \\
\text { to food safety practices by farmers and } \\
\text { salespeople }\end{array}$ & $\begin{array}{l}\text { Training in principles of good manu- } \\
\text { facturing practice, hazard analysis and } \\
\text { critical control points at farming and } \\
\text { wet market sites }\end{array}$ & $\begin{array}{l}\text { Wet market sales license only after food safety practice "train- } \\
\text { ing", "market" signs as reminders of "practices" and "regular", } \\
\text { fine enforced inspection of practices for food production and } \\
\text { sales personnel }\end{array}$ \\
\hline $\begin{array}{l}\text { Wild animal and peridomestic mammal } \\
\text { products }\end{array}$ & $\begin{array}{l}\text { Strict farm separation of wild animals } \\
\text { and peridomestic mammals from } \\
\text { conventional meat and seafood and } \\
\text { ban of products from these sources on } \\
\text { wet markets }\end{array}$ & $\begin{array}{l}\text { Grouped, fenced off and ideally covered farm areas by livestock } \\
\text { type with virus migration protection zones; separated produc- } \\
\text { tion facilities; frequent, unannounced controls of wet markets } \\
\text { products and a high fine for disregard of the ban }\end{array}$ \\
\hline Antibiotic-resistant pathogens & $\begin{array}{l}\text { Antibiotic-free farming and alter- } \\
\text { native production and wet market } \\
\text { sanitation }\end{array}$ & Use of non-antibiotic hurdle technologies \\
\hline $\begin{array}{l}\text { Cross-contamination due to unsafe wet } \\
\text { market installations }\end{array}$ & $\begin{array}{l}\text { Hygienic wet market installation } \\
\text { design }\end{array}$ & $\begin{array}{l}\text { Compartmentalization of sales area; clean display cases; } \\
\text { well-engineered drainage systems; sitting toilets instead of } \\
\text { squatting pan toilets; use of easy-to-sanitize materials }\end{array}$ \\
\hline $\begin{array}{l}\text { Danger of sharing contaminated wet market } \\
\text { food with family and friends, thereby, accel- } \\
\text { erating pathogen propagation }\end{array}$ & $\begin{array}{l}\text { Preparation instructions for handling } \\
\text { and cooking the wet market food pur- } \\
\text { chased and providing additional sets } \\
\text { of utensils for shared dishes }\end{array}$ & $\begin{array}{l}\text { Adequate food packaging; shelf life/use by dates; rinsing and } \\
\text { other pre-cooking treatment; cooking instructions to ensure } \\
\text { the products are not undercooked; proper disposal of waste }\end{array}$ \\
\hline $\begin{array}{l}\text { Lack of an early detection and documenta- } \\
\text { tion system to contain and trace outbreaks }\end{array}$ & $\begin{array}{l}\text { Preventive screening for emergence of } \\
\text { pathogens in wet markets }\end{array}$ & $\begin{array}{l}\text { Food safety control by taking product samples in defined inter- } \\
\text { vals to detect weak spots earlier and provide traceability }\end{array}$ \\
\hline
\end{tabular}

\section{Food Safety Education}

Farmers cultivating the food, in particular of animal origin, for wet markets and salespeople offering these products for market sale usually lack an adequate food safety education $[19,20]$. In addition, possible negligence during food production and handling by those with food safety knowledge is not remedied sufficiently by inspection personnel $[12,13]$. Periodic training in and controls of food safety practices are essential and considered an effective mitigation strategy [19] and these could be made conditional for obtaining a wet market delivery or selling license. As part of an effective implementation fines for grave food safety breaches need to be issued and also setup of reminder signs for wet market workers and customers, especially at identified critical control points, is recommended. Adhering strictly to established food safety systems (e.g. GMP, HACCP), that involve procedures such as mandatory hand washing [21], suitable food handling outfit and processing equipment (e.g. gloves, hairnets, cutting boards) [19], thorough food rinsing and separation[5], food and storage surfaces decontamination[11], and refrigeration[5], has proven to successfully prevent contamination with pathogens in the food industry and is therefore suggested to be applied to wet markets as well.

\section{Pathogen Contamination and Resistances}

Similar to the SARS CoV outbreak in 2002 the source of the SARS CoV2 is thought to be a wild animal virus, possibly originating in bats due to resemblance to the bat virus HKU9-1 [22], that has been passed on to civet cats, pangolins, or similar peridomestic 
mammals sold on wet markets $[10,16]$. Separation of these animals from those typically sold for human consumption on wet markets (e.g. poultry, cattle, pigs, seafood) will lower the risk of infection significantly. This can be achieved by grouping animals at safe distances from each other by means of fences, clearance zones, and covered livestock enclosures and also the separation for production facilities (e.g. breeding, feeding, and slaughtering grounds) is associated with a lower risk of contamination [5]. In addition, prohibition of sale for any wild animal and peridomestic mammal products at these markets, necessitating frequent, unannounced controls and high fine for violations, is suggested to further mitigate the possibility of contamination and transmission from animals to humans associated with wet markets.

Another potential hazard for wet market environments is antibiotic-resistant pathogens $[17,19]$, considering the generous use and prevalence of antibiotics in wet markets products [11], thus, suggesting the exclusion of antibiotics-based antimicrobials in farming and consideration of alternative production and wet market sanitation methods using hurdle technologies [23-25]. The latter should be non-antibiotic (e.g. by combining preservatives, nisin, bacteriophages, and ultraviolet light) to avoid the development of microbial resistances, that will otherwise make the medical treatment of those infected with antibiotic-resistant pathogens very challenging.

Moreover, the oftentimes insufficient conditions and layout of wet market facilities, that representa pathogen cross-contamination hazard, require a more sanitation-oriented wet market installations design. Typical market areas, that require modifications or reengineering to fulfill food safety standards and efficiently mitigate cross-contamination, fall into the aforementioned critical control points category, like public restrooms dominated by potentially less hygienic squatting toilets (Figure 1) [26,27], and slaughterhouses [5]. Sitting toilets and centralized abattoirs are respective implementation examples for enhanced hygienic design and better mitigation, as well as partitioned sales areas [5], closed storage cabinets for product display [28], sophisticated drainage systems [5], and the use of easy-to-sanitize materials [19] such as stainless steel or ceramics for market installations.

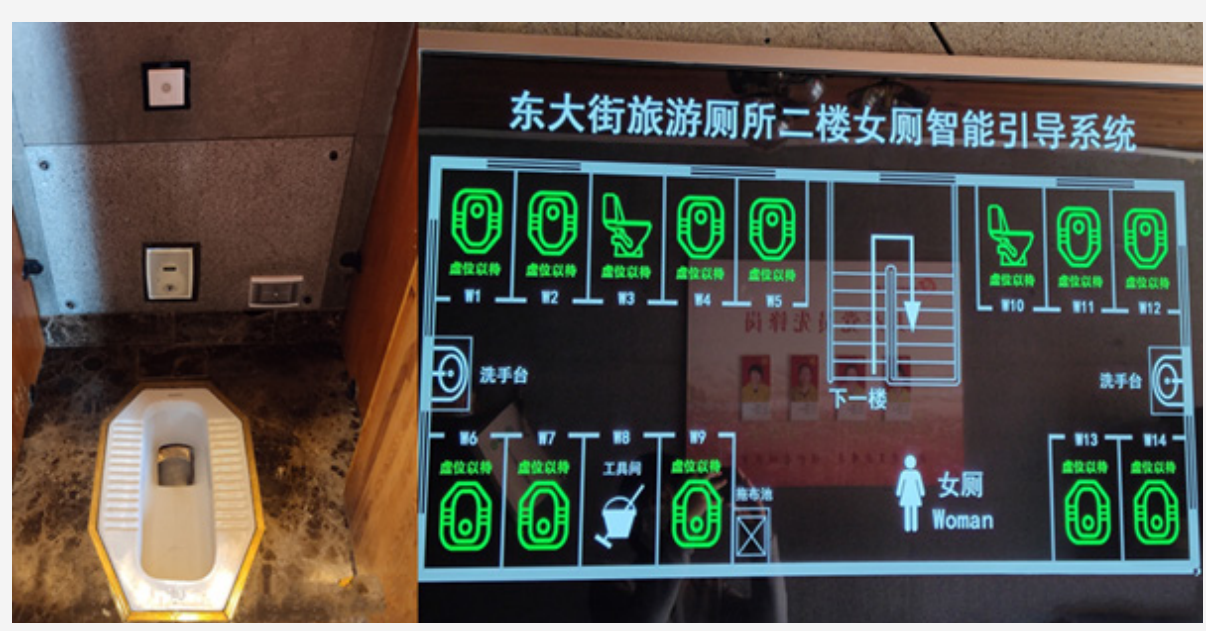

Figure 1: An example of a squatting toilet (left photo), with a higher contamination risk than a sitting toilet requiring a balanced posture and due to closer proximity to the floor, stool and infectious aerosols, and less contained cleaning space with potential cracks, and a toilet distribution ratio in a Chinese public restroom (right photo), 11 squatting vs. 2 sitting toilets.

Furthermore, shared meals among families and friends are, for instance, habitual in Asia and, if prepared from contaminated wet market food, could accelerate the distribution of pathogens. Consequently, a counter-measure has been announced in Guangzhou, China recently, stressing the importance of not using the personal set of chopsticks, accompanying a specific person's bowl or plate, for shared dishes, but adding a dedicated set of chopsticks for each shared dish to separately distribute these different foods to personal bowls or plates, lowering the risk of cross-contamination [29]. Hygiene-tailored food preparation guidance for consumers can also assist in mitigation of pathogen contamination during shared meals, implemented by appropriate food packaging and expiry dates, careful rinsing, and ensuring that the market products are not underprocessed and the waste is disposed safely.

\section{Early Detection and Traceability}

Significant neglects for the previous (2002) and current (2019) coronavirus outbreaks have been, that in either case the infection source could not be identified reliably, because an early detection and documentation system, enabling improved infection containment and traceability in case of a pathogen outbreak, has not been established for wet markets. However, wet markets can oftentimes function as early warning systems for the emergence of a pathogen outbreak [6]. Introducing a mitigation strategy that screens for and monitors emerging pathogens in wet markets is critical and can be put into action by product sampling and subsequent analysis on a regular basis to counteract any hazards as soon as possible. 
Last but not least, it is noteworthy, that these mitigation strategies need to be adapted to the market size and visitor numbers, which is also recommended for merging or enlarged food production facilities, where the production capacity is oftentimes substantially scaled up, but the food safety management system is not [30].

\section{Conclusion}

The mitigation strategies and examples for their implementation discussed in this review indicate, that the food safety hazards in wet markets can be prevented much more effectively than by following the current practice. By addressing the current shortcomings regarding food safety education, pathogen contamination and resistances, and devising a system for early detection and traceability wet markets can still be operated safely without the need for a ban. However, the character and atmosphere of wet markets upgraded with the proposed mitigation strategies will most certainly change, but the decline in market numbers may also be slowed and eventually halted by successful transformations. A new wet market tradition may have to be established, in which food safety takes priority, and this will also be reflected in more regulation and higher product prices as these changes need to be paid for.

\section{Acknowledgement}

The authors acknowledge funding for this work by the Guangdong Level-raising, Overall Development and Feature Strengthening Promotion Program for Higher Education.

\section{Conflict of Interest}

No conflict of interest.

\section{References}

1. WHO (2020) Coronavirus disease 2019 (COVID-19) Situation Report 39. World Health Organization Situation Reports, pp. 1-7.

2. MacKenzie D (2020) Covid-19: Why Won't the WHO officially declare a coronavirus pandemic. New Sci.

3. People's Daily Online (2020) 159 farmers markets in Nanjing resume business. Yangzi Evening News.

4. McNeil S, Wang PY, Kurtenbach E (2020) China imposes temporary ban on wildlife trade amid coronavirus outbreak. Global News.

5. Ho HF (2014) Wet Markets. In: Devine C, Dikeman M, Encyclopedia of Meat Sciences. $2^{\text {nd }}$, Academic Press, London, UK, pp. 244-247.

6. Webster RG (2004) Wet markets-a continuing source of severe acute respiratory syndrome and influenza? Lancet 363(9404): 234-236.

7. Tsuchiya K, Hara H, Thaitakoo D (2015) Linking food sand land systems for peri-urban agriculture in Bangkok Metropolitan area. Landsc Urban Plan 143: 192-204.

8. Sharif MSM, Nor NM, Zaharia MSM, Muhammad R (2015) Following mothers to the wet market: The significant benefits gain by young generations. Procedia Soc Behav Sci 170: 197-205.

9. Bhowmik S, Begum M, Hossain MA, Rahman M, Nowsad Alam, AKM (2017) Determination of formaldehyde in wet marketed fish by HPLC analysis: A negligible concern for fish and food safety in Bangladesh. Eqypt J Aquat Res 43(3): 245-248.

10. Tung KC, Hsiao FC, Wang KS, Yang CH, Lai CH (2013) Study of the endoparasitic fauna of commensal rats and shrews caught caught in traditional wet markets in Taichung city, Taiwan. J Microbiol Immunol Infect 46(2): 85-88.

11. Nguyen TN, Nguyen TBV, Nguyen VC, Truong TQD, Tran TN, et al. (2018) Antimicrobial residues and resistance against critically important antimicrobials in non-typhoidal Salmonella from meat sold at wet markets and supermarkets in Vietnam. Int J Food Microbiol 266: 301309.

12. Chrun R, Hosotani Y, Kawasaki S, Inatsu Y (2017) Microbiological hazard contamination in fermented vegetables sold in local markets in Cambodia. Biocontrol Sci 22: 181-185.

13. Boseley S (2020) Calls for global ban on wild animal markets amid coronavirus outbreak. The Guardian.

14. Walzer C, Kang A (2020) Abolish Asia's 'wet markets', where pandemics breed. Wall Street Journal.

15. Guan W, Ni Z, Hu Y, Liang W, Ou C, et al. (2020) Clinical characteristics of 2019 novel coronavirus infection in China. N Engl J Med (in press).

16. Root JJ, Bosco Lauth AM, Bielefeldt Ohmann H, Bowen RA (2016) Experimental infection of peridomestic mammals with emerging H7N9 (A/Anhui/1/2013) influenza A virus: Implications for biosecurity and wet markets. Virol 487: 242-248.

17. Gao XL, Shao MF, Luo Y, Dong YF, Ouyang F, et al. (2016) Airborne bacterial contaminations in typical Chinese wet market with live poultry trade. Sci Total Environ 572: 681-687.

18. WHO (2020) Coronavirus disease 2019 (COVID-19) Situation Report 43. World Health Organization Situation Reports, pp. 1-7.

19. Lo MY, Ngan WY, Tsun SM, Hsing HL, Lau KT, et al. (2019) A field study into Hong Kong's wet markets: Raised questions into the hygienic maintenance of meat contact surfaces and the dissemination of microorganisms associated with nosocomial infections. Front Microbiol 10: 2618 .

20. Hung NV, Tran TTH, Unger F, Sinh DX, Grace D (2017) Food safety in Vietnam: where we are at and what we can learn from international experiences. Infect Dis Poverty 6(1): 39.

21. Wu D, Lam TP, Chan HY, Lam KF, Zhou XD, et al. (2019) A mixed methods study on toilet hygiene practices among Chinese in Hong Kong. BMC Public Health 19(1): 1654.

22. Xu X, Chen P, Wang J, Feng J, Zhou H, et al. (2020) Evolution of the novel coronavirus from the ongoing Wuhan outbreak and modeling of its spike protein for risk of human transmission. Sci China Life Sci (in press).

23. Ahmadi H, Anany H, Walkling-Ribeiro M, Griffiths MW (2015) Biocontrol of Shigella flexneri in ground beef and Vibrio cholerae in seafood with bacteriophage-assisted high hydrostatic pressure (HHP) treatment. Food Bioprocess Technol 8: 1160-1167.

24. Kim SH, Shahbaz HM, Park D, Chun S, Lee W, et al. (2017) A combined treatment of UV-assisted $\mathrm{TiO} 2$ photocatalysis and high hydrostatic pressure to inactivate internalized murine norovirus. Innov Food Sci Emerg Technol 39: 188-196.

25. Sikin, AM, Walkling-Ribeiro M, Rizvi SSH (2017) Synergistic processing of skim milk with high pressure nitrous oxide, heat, nisin, and lysozyme to inactivate vegetative and spore-forming bacteria. Food Bioprocess Technol 10: 2132-2145.

26. Afacan Y, Gurel MO (2015) Public toilets: an exploratory study on the demands, needs, and expectations in Turkey. Environ Plan B: Urban Anal City Sci 42: 242-262.

27. China National Working Committee on Children and Women under State Council (2020) Urban public toilet design standard/technical standardurban toilet.

28. People's Daily Online (2020) Hangzhou strengthens food safety supervision. Hangzhou Daily.

29. Zeng F, He D, Zhao D (2020) Please spread public chopsticks at the table. Guangzhou Daily. 
30. Griffiths MW, Walkling-Ribeiro M (2012) Microbial decontamination of milk and dairy products. In: Demirci A, Ngadi MO. Microbial decontamination in the Food Industry: Novel Methods and Applications, Woodhead Publishing Ltd, Cambridge, UK, pp. 190-238. 